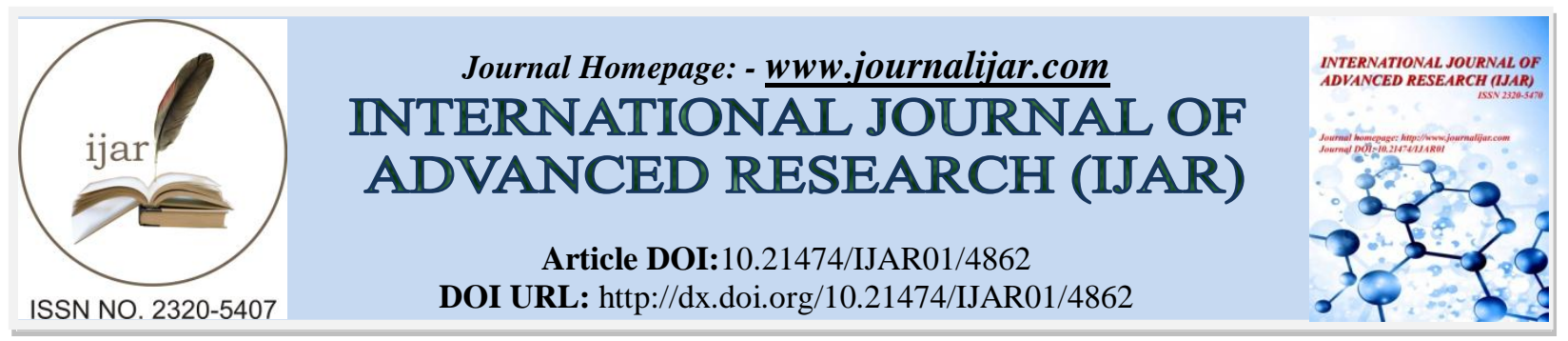

RESEARCH ARTICLE

\title{
IN VITRO MICROPROPAGATION OF STACHYTARPHETA JAMAICENSIS L.VAHL., AN ETHNOMEDICINAL PLANT AND CONFIRMATION OF GENETIC FIDELITY OF THE PLANTLETS USING RAPD MARKERS.
}

\author{
Korra Rajender ${ }^{1}$, Bylla Prasad ${ }^{2}$, Gulab Khan Rohela ${ }^{3}$, Sreenu Pendli ${ }^{1}$ and ${ }^{*}$ T. Christopher Reuben' \\ 1. Department of Botany, Kakatiya University, Warangal- 506009, Telangana, India. \\ 2. Department of Biotechnology, Kakatiya University, Warangal- 506009, Telangana, India. \\ 3. Molecular Biology Section, Central Sericultural Research \&Training Institute, Central Silk Board, Ministry of \\ Textiles, Government of India, Pampore, Jammu \& Kashmir, India
}

\section{Manuscript Info}

Manuscript History

Received: 15 May 2017

Final Accepted: 17 June 2017

Published: July 2017

\section{Key words:-}

Stachytarphetajamaicensis, Shoot tip, RAPD, Acclimatization.

\section{Abstract}

In vitro shoots proliferated from shoot tip explants on MS medium supplemented with various concentrations of BAP, KN \& TDZ and rooting of individual shoots occurred on MS medium supplemented with various concentration of IBA, IAA \& NAA in Stachytarpheta jamaicensis L. Vahl. Maximum number of shoots \& longest shoot length $(\mathrm{cm})(1.96 \pm 0.17) \&(2.34 \pm 0.16)$ respectively, were produced on MS + TDZ $(0.5 \mathrm{mg} / \mathrm{L})$, after 4 weeks of culture. Maximum number of roots and longest root length $(\mathrm{cm})(2.67 \pm 0.88) \&(3.33 \pm 0.33)$ respectively, were produced on MS + IBA $(0.5 \mathrm{mg} / \mathrm{L})$, after 4 weeks of culture. The rooted plantlets $\left(\mathrm{R}_{1}\right)$ were acclimatized in green house for 4 weeks and then transferred to field conditions with $69 \%$ survivability. RAPD primer OPE-20 banding pattern of $\mathrm{R}_{1}$ plantlets was similar to that of mother plant.

Copy Right, IJAR, 2017,. All rights reserved.

\section{Introduction:-}

Stachytarpheta jamaicensis L.Vahl (Verbenaceae), commonly known as Kukurdanti (Gervao), is native to Brazil, Cuba, Mexico and India. It is an annual and sometimes perennial herbaceous plant that grows $1.3 \mathrm{~m}$ tall and $1.6 \mathrm{~m}$ wide, before stems droop and touches the ground ${ }^{1}$. It has been in use as a traditional medicinal plant for many years; leaves are used to treat dysentery and intestinal worms ${ }^{2}$. In many countries, it is in use as herbal medicine for curing allergies, stomach problems, intestinal parasites, for stimulating digestion, suppressing cough, reducing fever, expelling worms, increasing perspiration, promoting menstruation, treating diarrhea and also has antimicrobial activity $^{3}$. S. jamaicensis is also used as an antacid, analgesic, anti-inflammatory, diuretic, hypertensive, laxative, sedative, stomach tonic, spasmogenic, vulmerary and vermifuge ${ }^{4}$. Externally it is used to clean ulcers, cuts and wounds ${ }^{5}$. In Malaysia, a decoction of the leaves is used as a draught for ulceration of the nose and as an antiperiodic medicine in malaria.

Several phytochemicals have been reported from S. jamaicensis such as alkaloids ${ }^{6}$, ipolamide, hispidulin, beta hydroxyipolamide, verbascoside ${ }^{4,7}$, steroids, triterpenes and irridoids ${ }^{8}$. Verbascoside has many potential applications such as, it is used as an antimicrobial compound ${ }^{9}$ against many bacterial pathogens, including Staphylococcus aureus $^{10}$. It is also in use as an anti-inflammatory compound ${ }^{11}$. Similarly, verbascoside is reported to have anti- 
proliferative properties against human lymphocytic cancer cells. It is well known that verbascosides interacts with PARP-1 and p53 proteins ${ }^{12}$ and shows inhibitory activity on the protein kinase $\mathrm{C}$ enzyme ${ }^{13}$.

In recent times, $S$. jamaicensis has been exploited commercially for its phytoconstituents and there is an urgent need to conserve this plant species for present and future use of its medicinal compounds.

\section{Materials and Methods:- \\ Preparation of explants:-}

Healthy shoot tips of $S$. jamaicensis were obtained from 6-8 months old well established plants growing in the research field of the Department of Botany, Kakatiya University, Warangal, India. The shoot tip includes the apical dome and 3-4 leaf primordia. The harvested shoot tip explants were washed under running tap water thoroughly and then rinsed with Tween-20 detergent solution for 10 minutes.

\section{Preparation of MS Media:-}

Full strength plant tissue culture media was prepared by taking 4.4 grams of readymade $\mathrm{MS}^{14}$ medium powder (Himedia) and 25 grams of sucrose in $500 \mathrm{ml}$ of distilled water and the final the volume was made up to $1000 \mathrm{ml}$. The $\mathrm{pH}$ of the media was adjusted to 5.8 using $0.1 \mathrm{~N} \mathrm{NaOH}$ and the media was solidified with $0.8 \%$ agar before autoclaving.

\section{Inoculation:-}

The explants were surface sterilized with $0.1 \% \mathrm{HgCl}_{2}$ for 2-3 minutes under laminar air flow conditions and then washed with sterile distilled water. Shoot tip explants ranging from 0.5 to $1.0 \mathrm{~cm}$ in length were inoculated on to MS medium with different concentrations $(0.5,1.0,1.5$ or $2,0 \mathrm{mg} / \mathrm{L})$ of Benzylaminopurine (BAP), $(0.5,1.0,1.5$ or 2.0 $\mathrm{mg} / \mathrm{L})$ of Kinetin $(\mathrm{Kn})$ and $(0.5,1.0,1.5$ or $2.0 \mathrm{mg} / \mathrm{L})$ of Thidiazuron (TDZ). All cultures were maintained in a culture room at $25 \pm 2^{\circ} \mathrm{C}$ with a relative humidity of $70 \%$ and a 16 hours photoperiod at a photon flux density of 18 $20 \mu \mathrm{E} \mathrm{m}^{-2} \mathrm{~s}^{-1}$ from cool white fluorescent tubes.

\section{In vitro Rooting:-}

Well developed shoots measuring $2.5 \mathrm{~cm}$ in length were cultured separately on MS medium with different concentrations $(0.25,0.50,0.75$ or $1.00 \mathrm{mg} / \mathrm{L})$ of Indole-3- acetic acid (IAA), or Indole-3- butyric acid (IBA) or Napthalene acetic acid (NAA).

\section{Acclimatization and hardening:-}

Rooted plantlets $\left(\mathrm{R}_{1}\right)$ were transferred to MS basal medium and grown under diffuse light in the culture room for 3 weeks. They were then transferred to plastic pots containing a mixture of sand, loamy soil and vermiculite in the ratio of 2:1:1(w: w) and grown in a green house for another 4 weeks. Hardened $\mathrm{R}_{1}$ plantlets were transplanted in the departmental research field.

\section{RAPD Analysis:-}

Genomic DNA was extracted from $1 \mathrm{~g}$ fresh leaf tissue of 03 randomly picked $\mathrm{R}_{1}$ plantlets and a control (mother) plant using the CTAB method ${ }^{15}$. DNA concentration and quality were evaluated at 260 and $280 \mathrm{~nm}$. The $\mathrm{A}_{260 / 280}$ ratio ranged between 1.8 and 1.9. DNA integrity was confirmed by gel electrophoresis on $1 \%$ Agarose on TAE buffer (10M Tris HCl, 10M EDTA, pH 8.3). The RAPD primers (OPE 1-20) (Bioserve, Hyderabad) were used for PCR amplification of genomic DNA of $\mathrm{R}_{1}$ plantlets and the control (mother) plant. PCR amplification was carried out in $20 \mu \mathrm{l}$ reaction volume containing $2.0 \mu \mathrm{l}$ of $1.25 \mathrm{mM}$ each of dNTPs, $1 \mu \mathrm{l}$ of the primer, 1x Taq polymerase buffer, $0.5 \mathrm{U}$ of Taq DNA polymerase (GeNei, India) and $2 \mu 1$ (20ng) of genomic DNA.

DNA amplification was performed in a DNA Thermocycler (Biorad USA) which was used for initial DNA denaturation at $95^{\circ} \mathrm{C}$ for $5 \mathrm{~min}, 1 \mathrm{~min}$ annealing at $37^{\circ} \mathrm{C}$ and $2 \mathrm{~min}$ extension at $72^{\circ} \mathrm{C}$, followed by one final extension at $72^{\circ} \mathrm{C}$ for $10 \mathrm{~min}$. Amplified products were resolved by electrophoresis on $1.2 \%(\mathrm{w} / \mathrm{v}$ ) Agarose (Sigma, USA) gel in Tris-Borate EDTA (TBE) buffer, stained with Ethidium bromide and photographs were taken by a gel documentation system (Biorad USA). The size of the amplification products was estimated using a $3 \mathrm{kbp}$ ladder (Takara, China). All the reactions were repeated at least thrice to check for reproducibility. 


\section{Statistical Analysis:-}

All the experiments were repeated thrice with 12 replicates. The effect of different treatments was summarized as mean \pm S.E and the data were subjected to statistical analysis using Duncan's Multiple Range Test (DMRT) at 5\% $\& 1 \%$ level significance ${ }^{16}$.

\section{Results and Discussion:-}

Percentage of shoot regeneration, mean number of shoots per culture and shoot length $(\mathrm{cm})$ was scored in shoot tip explants cultured on MS media supplemented with either BAP or Kn or TDZ at 0.5,1.0,1.5 \& $2.0 \mathrm{mg} / \mathrm{L}$ each, in $S$. jamaicensis, after 4 weeks of culture (Fig-1-3). Highest percentage of shoot regeneration $(88,72,60)$, maximum number of shoots/ explant $(1.96 \pm 0.17,1.72 \pm 0.24 \& 1.68 \pm 0.04)$ with longest shoot length $(\mathrm{cm})(2.34 \pm 0.16$, $1.66 \pm 0.28 \& 1.62 \pm 0.19)$ was observed on MS + TDZ $(0.5 \mathrm{mg} / \mathrm{L}), \mathrm{MS}+\mathrm{Kn}(1.0 \mathrm{mg} / \mathrm{L}) \& \mathrm{MS}+\mathrm{BAP}(1.5 \mathrm{mg} / \mathrm{L})$ respectively.

Similar reports regarding the usage of BAP, Kn and TDZ in shoot proliferation and multiple shoot induction from nodal and shoot tip explants are available in literature. Efficiency of BAP in causing shoot regeneration from shoot tip explants of Vitexagnus-castus has been reported from nodal segments in Vitex trifolia. ${ }^{17-19}$. Sujatha et al ${ }^{20}$ has induced the multiple shoots $(4.55 \pm 0.25$ and $3.70 \pm 0.25)$ in sponge gourd (Luffa cylindrica L.) by using $1.5 \mathrm{mg} / \mathrm{L}$ concentration of BAP from leaf and nodal explants respectively. Rohela et al. ${ }^{21}$ has induced multiple shoots $(6.1 \pm$ 0.64 and $6.7 \pm 0.52$ ) from nodal and shoot tip explants respectively in Rauwolfia tetraphylla $\mathrm{L}$. by using $2.5 \mathrm{mg} / \mathrm{L}$ concentration of BAP.

TDZ was reported earlier as a potent cytokinin in inducing shoot proliferation in shoot tip and nodal explants of different plants and also TDZ is quite stable in in vitro culture conditions and it is resistant to cytokinin oxidases, hence it presently used by most plant tissue culturists across the world ${ }^{22}$. Rohela et al. ${ }^{23-25}$ has used the MS+TDZ+BAP combination for the in vitro shoot regeneration from calli derived from leaf and stem explants of Rauwolfia tetraphylla $\mathrm{L}$.

The proliferated shoots of $S$. jamaicensis were then tested for root induction by transferring the individual shoots on to different types of auxins (IBA, NAA\& IAA) containing media (Fig-4-6). Among different auxins used, IBA has shown good response in root induction; more number of roots with maximum root length $(\mathrm{cm})(2.67 \pm 0.88) \&$ $(3.33 \pm 0.33)$ was obtained on MS + IBA $(0.5 \mathrm{mg} / \mathrm{L})$ after 4 weeks of culture. Even though root initiation was also observed on NAA and IAA containing media, the results were not comparable to that of IBA.

In vitro plantlet formation from shoot tip explants of $S$. jamaicensis grown on MS medium supplemented with various concentration of BAP, Kn, TDZ, IBA is given in Fig 7 a-f. The rooted plantlets $\left(\mathrm{R}_{1}\right)$ were hardened in pots containing 2:1:1 ratio of sand, loamy soil and vermiculite and then they were acclimatized initially in green house for 4 weeks and then transferred to field conditions with $69 \%$ survivability.

Genetic fidelity of plantlets was confirmed by using RAPD primers. Among the different primers used, RAPD primer OPE-20 has shown 08 bands in $\mathrm{R}_{1}$ plantlets within the range of $0.3 \mathrm{Kbp}$ to $1.3 \mathrm{Kbp}$ which was similar to that of control (mother) plant (Fig-8). RAPD primers were earlier reported for both DNA profiling and genetic fidelity studies in several plant species. Prasad et al. ${ }^{26}$ has reported DNA profiling of chilli peppers by using RAPD primers. Similarly, RAPD primers were used for analyzing genetic fidelity of Populus deltoides ${ }^{27}$, Morus alba ${ }^{28}$, Swertia chirayita $^{29}$. 


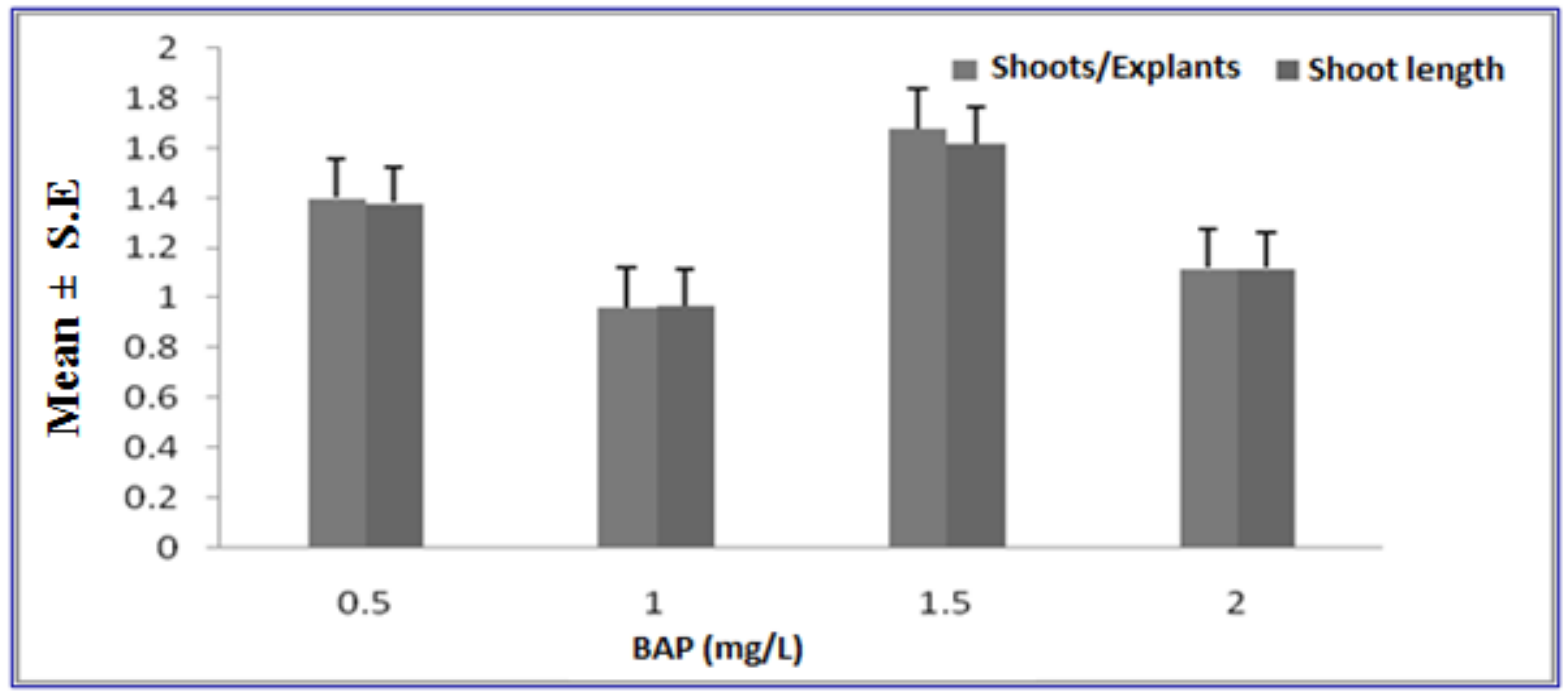

Fig.1:- In vitro shoot proliferation from shoot tip explants of $S$. jamaicensis cultured on MS+ BAP (0.5-2.0 mg/L), after 4 weeks of culture

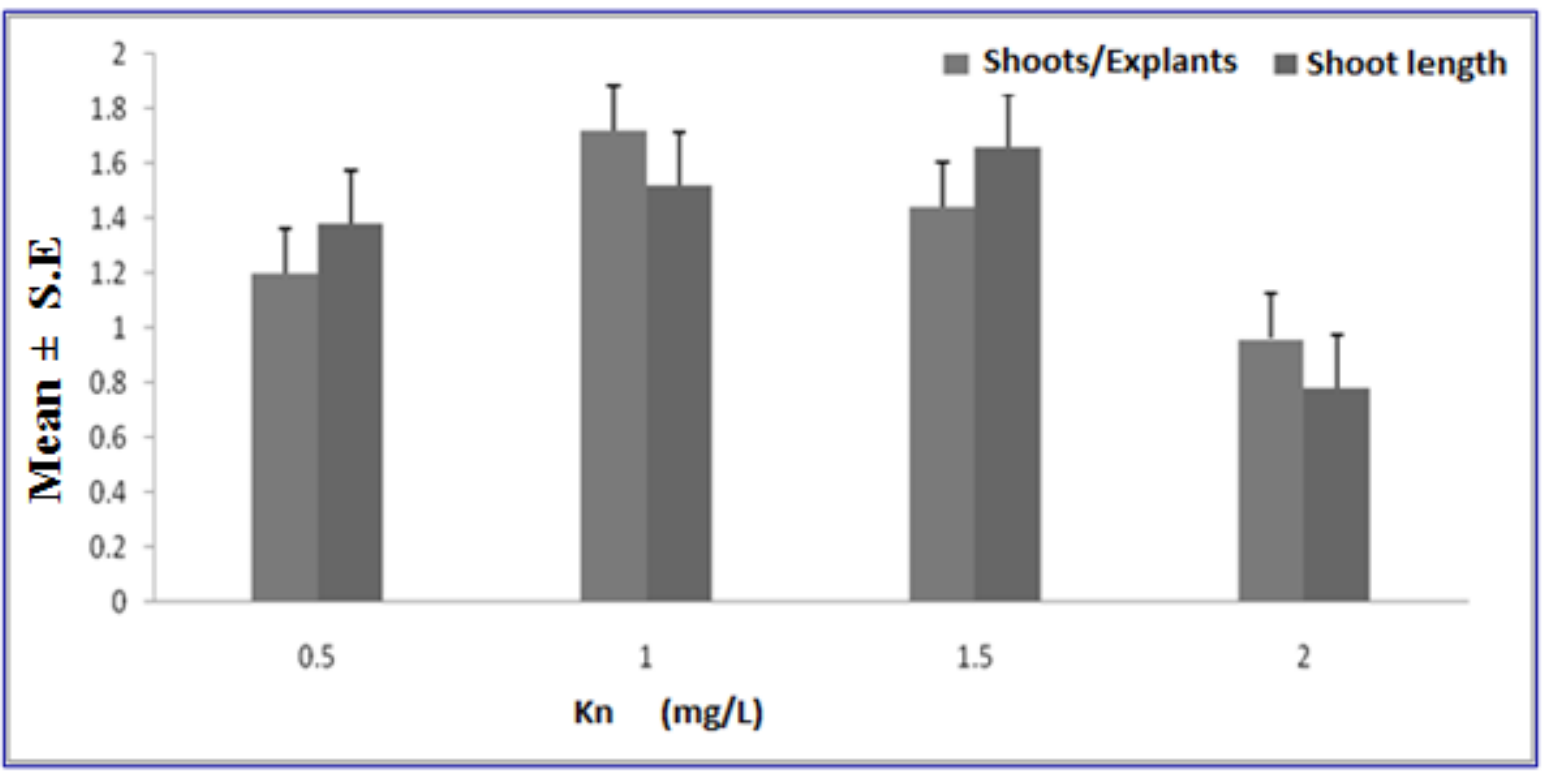

Fig.2:- In vitro shoot proliferation from shoot tip explants of $S$. jamaicensis cultured on MS+ Kn (0.5-2.0 mg/L), after 4 weeks of culture 


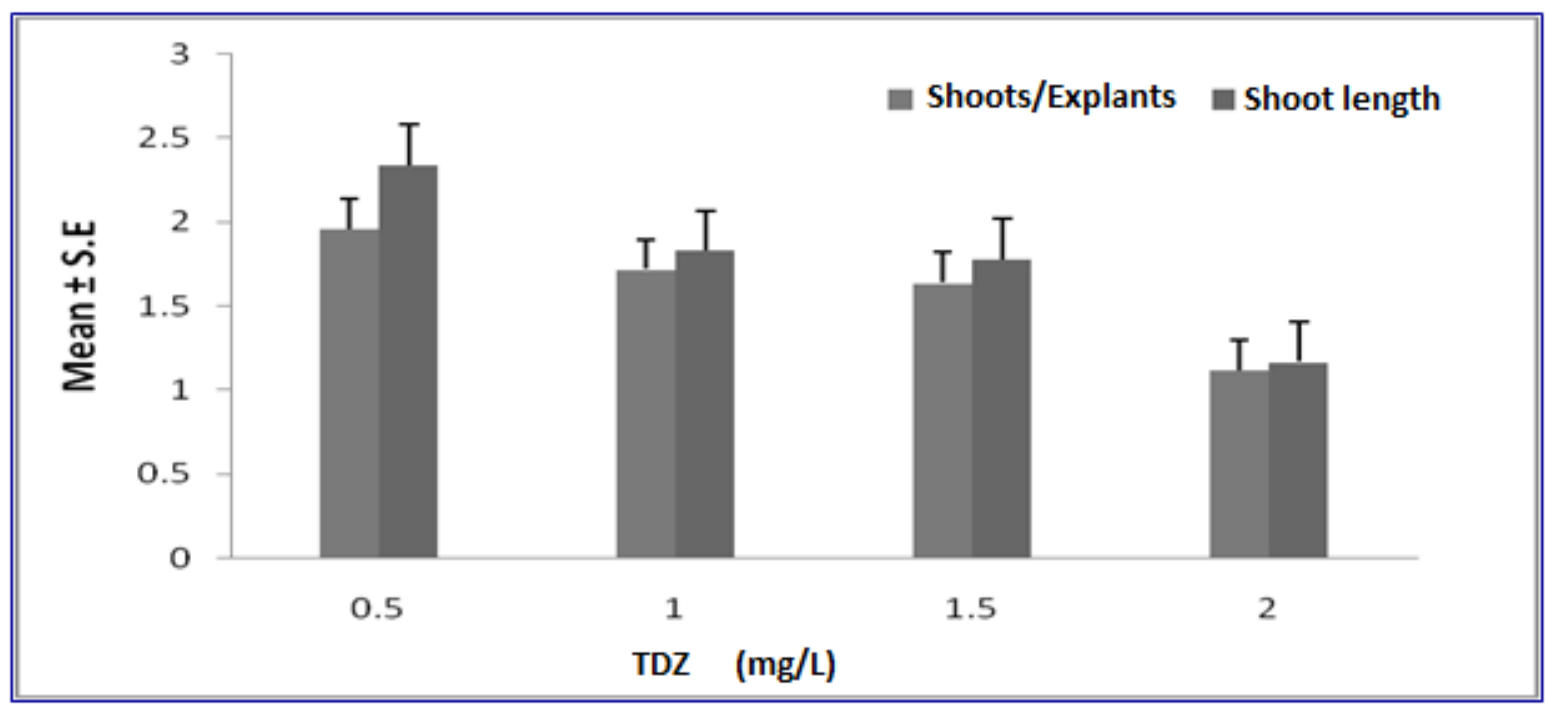

Fig.3: In vitro Shoot proliferation from shoot tip explants of $S$. jamaicensis cultured on MS+ TDZ(0.5-2.0 mg/L), after 4 weeks of culture

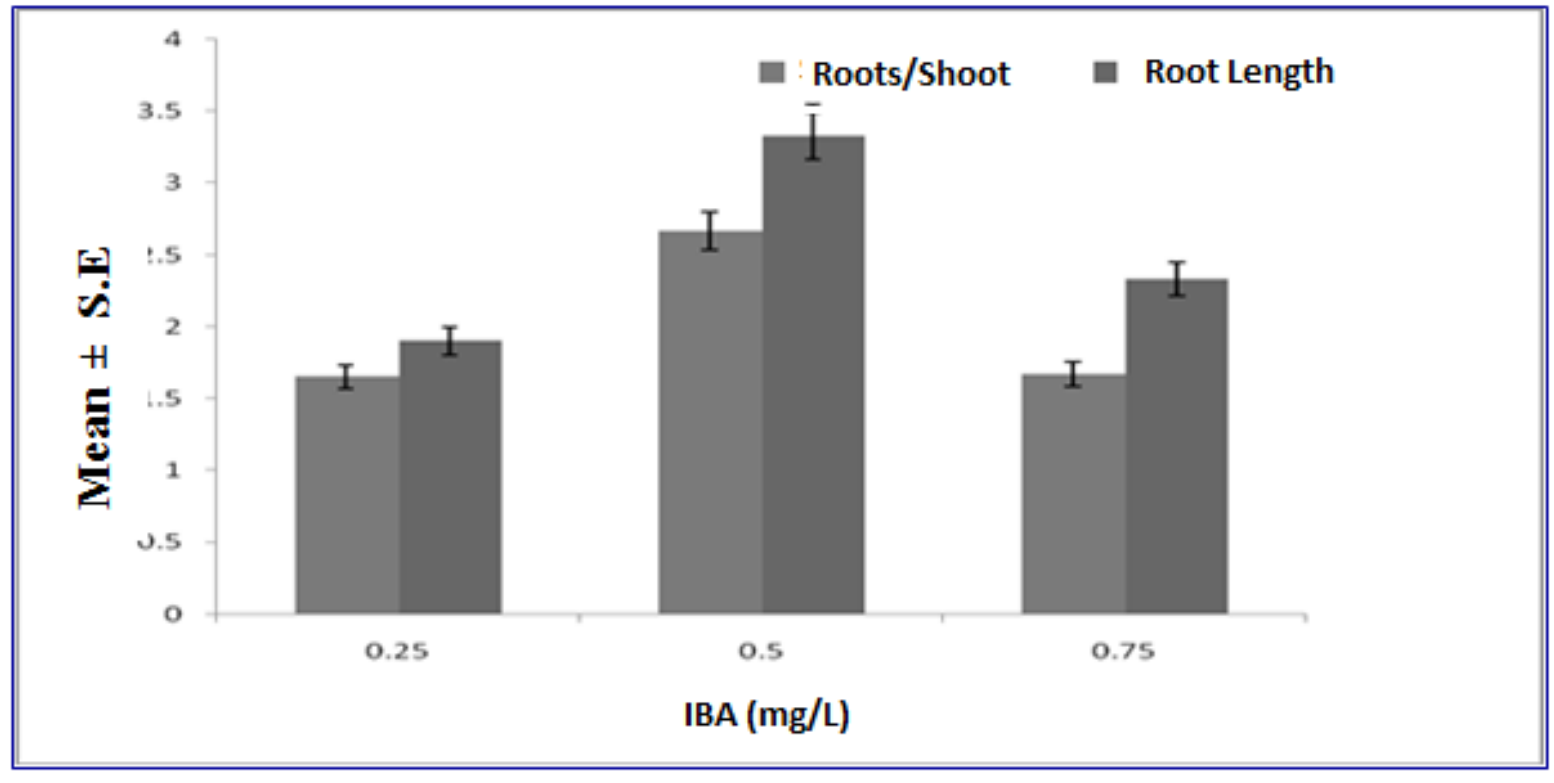

Fig.4: In vitro root induction in shoots of $S$. jamaicensis cultured on MS+ IBA (0.25-0.75 mg/L), after 4 weeks of culture 


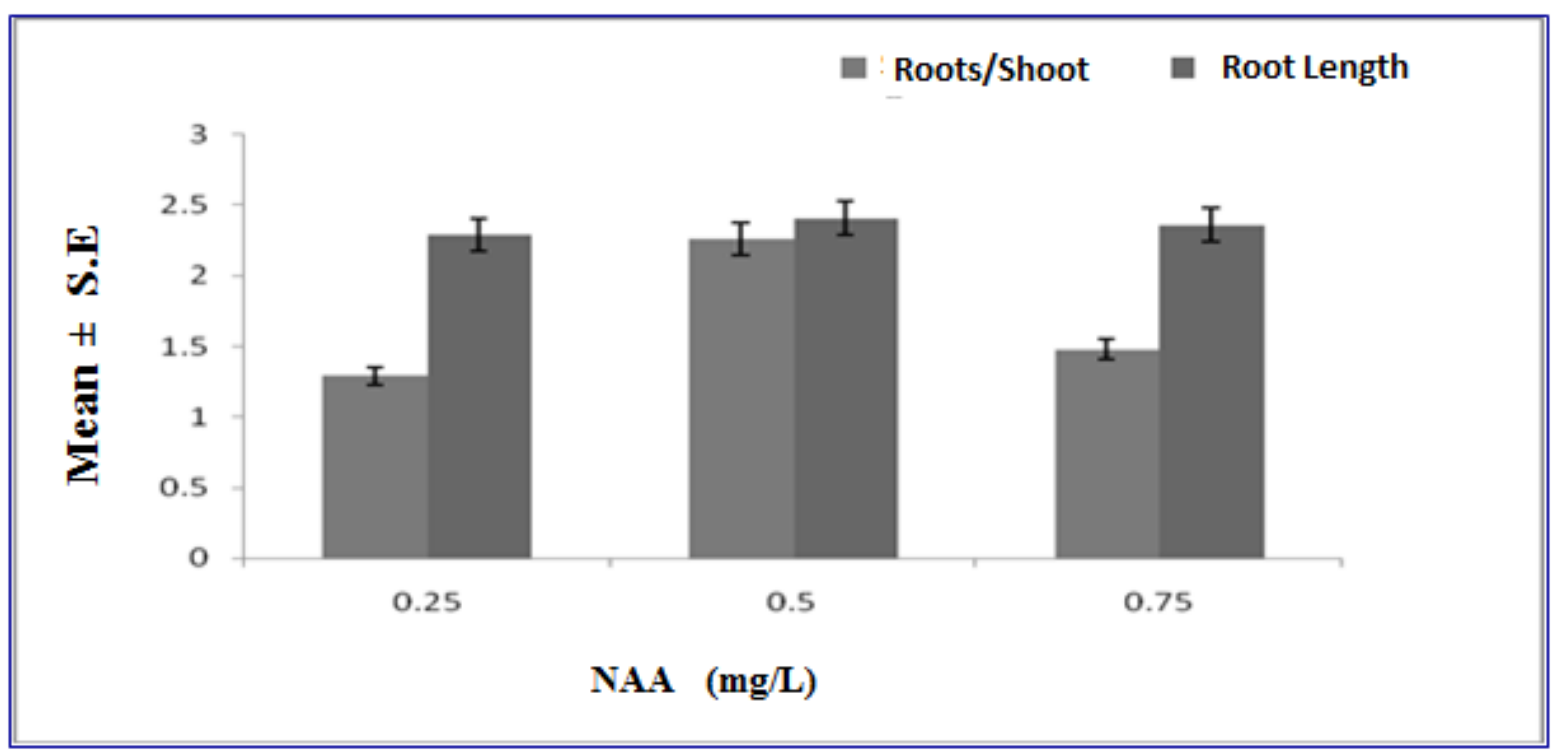

Fig.5: In vitro root induction in shoots of $S$. jamaicensis cultured on MS+ NAA (0.25-0.75 mg/L), after 4 weeks of culture

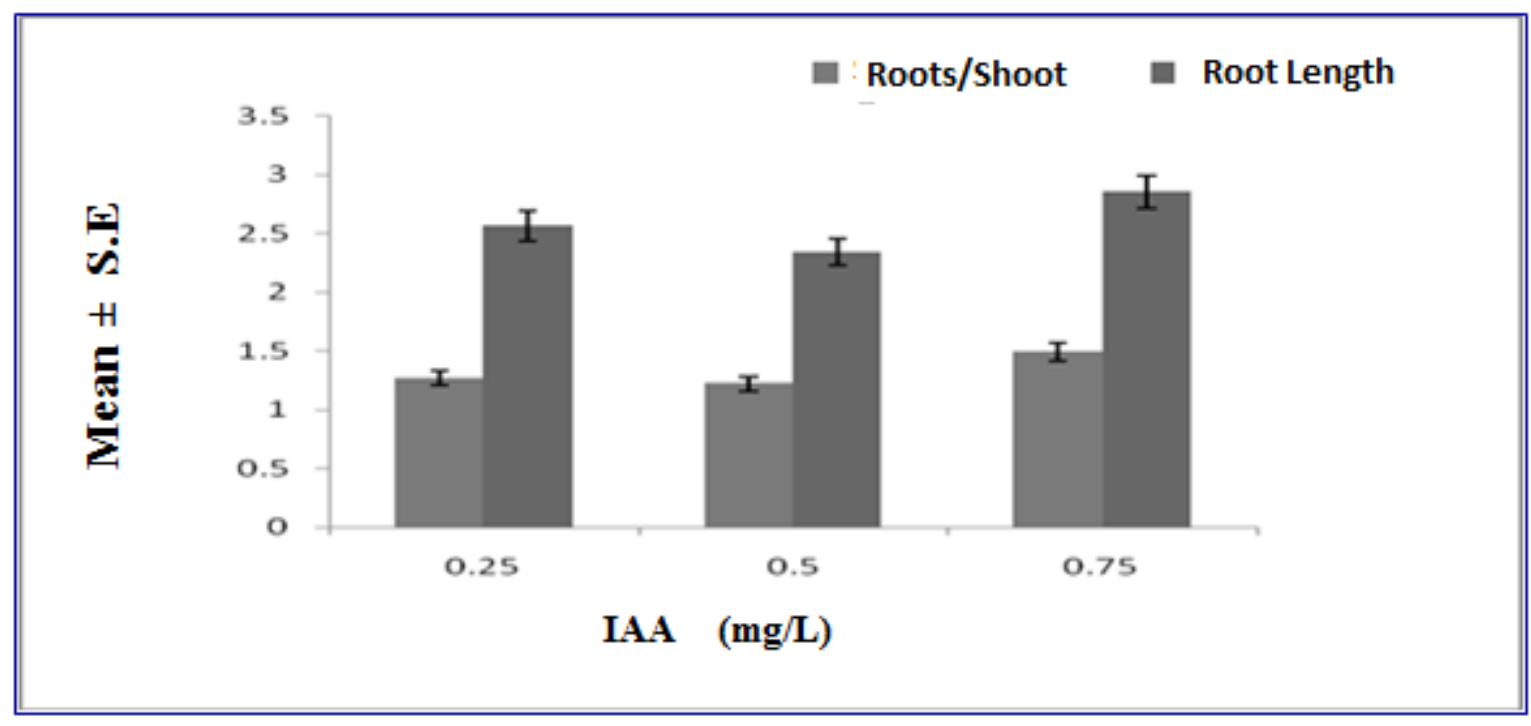

Fig.6: In vitro root induction in shoots of $S$. jamaicensis cultured on MS+ IAA (0.25-0.75 mg/L), after 4 weeks of culture 


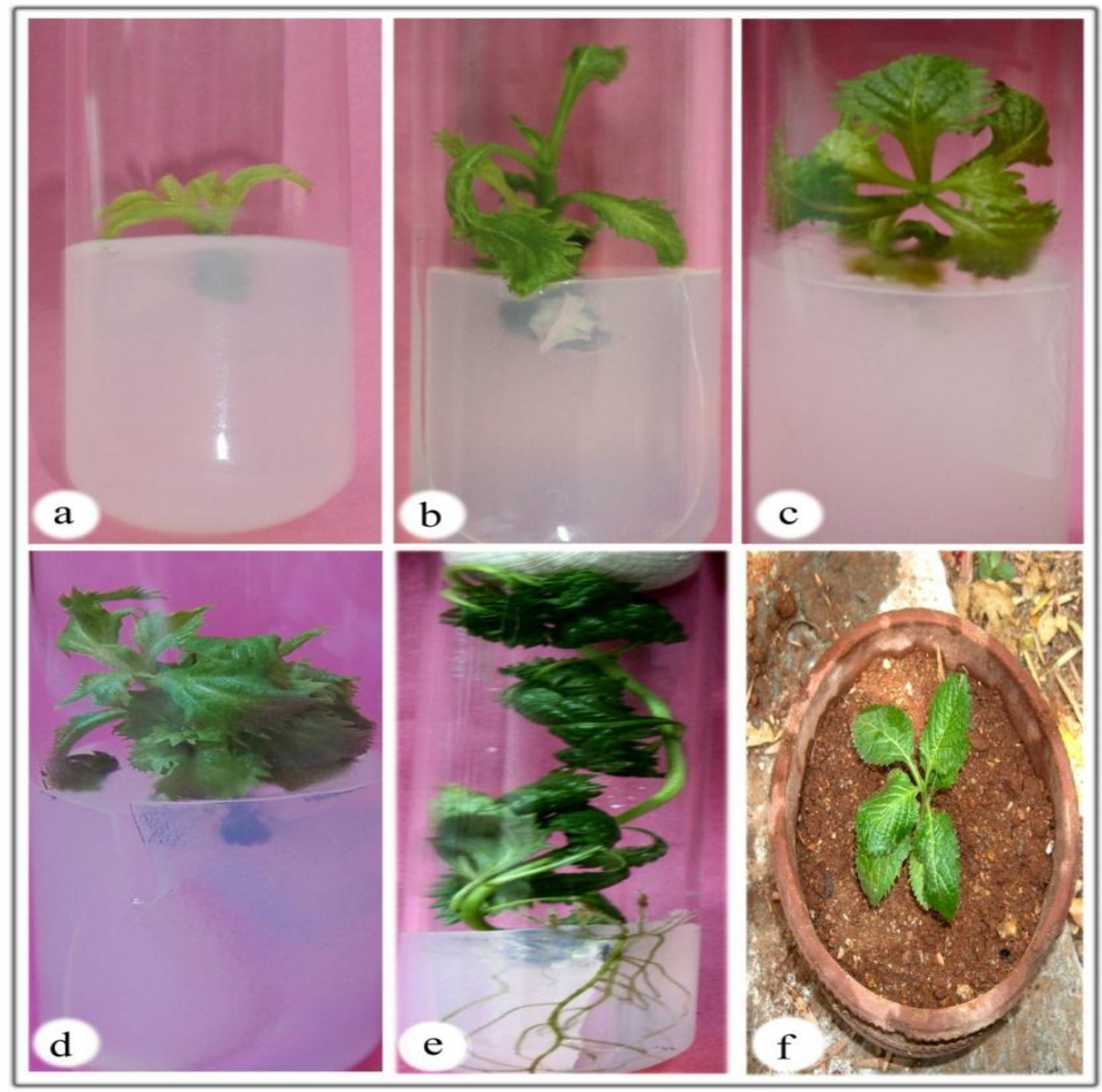

Fig 7:- In vitro shoot proliferation in shoot tip explants of $S$. jamaicensis grown on MS Medium supplemented with various concentration of BAP, Kn, TDZ, IBA after 4 weeks of culture

a) Shoot proliferation on $\mathrm{MS}+0.5 \mathrm{mg} / 1$ and $1.5 \mathrm{mg} / 1 \mathrm{BA}$ after one week culture

b) Shoot proliferation on $\mathrm{MS}+1.0 \mathrm{mg} / \mathrm{l}$ and $1.5 \mathrm{mg} / \mathrm{l} \mathrm{Kn}$ after two weeks culture

c) Shoot proliferation on MS+0.5mg/1 TDZ after two weeks of culture

d) Separated shoot cultured on MS+ IBA $(0.5 \mathrm{mg} / \mathrm{l})$

e) Root induction in shoots on $\mathrm{MS}+0.5 \mathrm{mg} / 1 \mathrm{IBA}$

f) Fully developed plantlet growing in pot after hardening process 


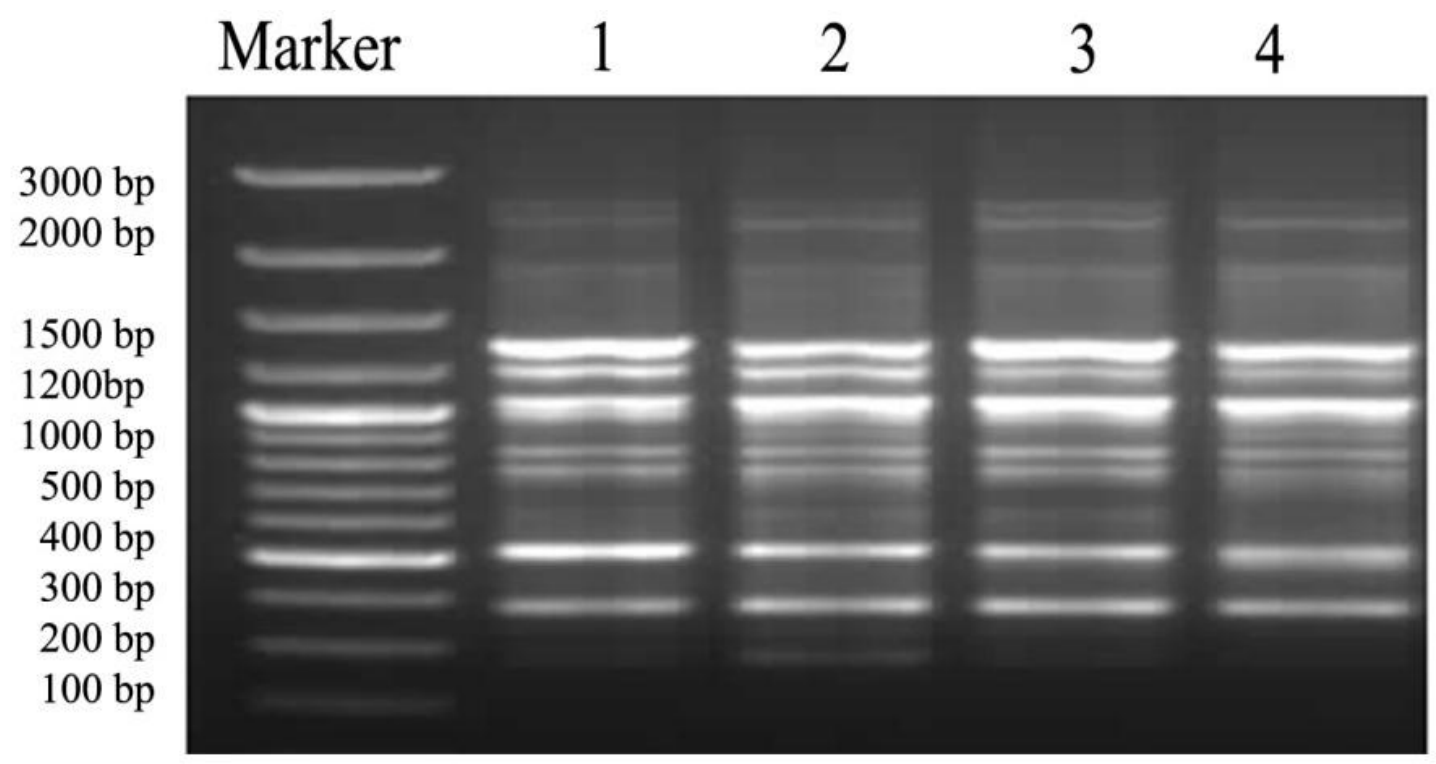

Fig 8:- RAPD profiling of $\mathrm{R}_{1}$ plantlets and control (mother) plant of Stachytarpheta jamaicensis using OPE-20

Line M: Marker, primer:

Line 1: Control (mother) plant of $S$. jamaicensis grown in research field,

Line 2-4: $\mathrm{R}_{1}$ plantlets of $S$. jamaicensis grown in research field,

\section{Conclusion:-}

In the present study an efficient protocol for in vitro proliferation of multiple shoots from shoot tip explants in $S$. jamaicensis was developed. RAPD marker (OPE-20) was used to assess the genetic fidelity was demonstrated in $\mathrm{R}_{1}$ plantlets. So the present study can be applied for clonal propagation of medicinally important $S$. jamaicensis.

\section{Acknowledgement:-}

The first author is grateful to the UGC for financial assistance under Post Doctoral Fellowship (PDF). Authors thank Dean, Faculty of Science, Head, Department of Botany and Chairman, BOS for providing necessary facilities to carry out the research work.

\section{Conflict of Interest:-}

Authors do not have any conflict of interest

\section{References:-}

1. Gilman EF.Codiaeum variegatum.(1999). Institute of food and agriculture sciences, University of Florida USA), Fps, 559pp.

2. Robinson RD, Williams LA, Lindo JF, Terry SI, Mansingh, A.W. (1990). Inactivation of Strongyloides stercoralis filariform larvae in vitro by six Jamaican plant extracts and three commercial anthelmintics. Indian Med J, 39 (4), 213-217. PMID: 2082565

3. Sasidharan S, Yogalatha L, Zuraini Z, Suryani S, Sangeetha S. (2007). Antidiarrheal and antimicrobial activities of Stachytarpheta jamaicensis leaves. Indian J Pharmcol; 39, 245-248. doi: 10.4103/0253-7613.37276

4. Schapoval EE, Vargas MR, Chaves CG, Bridi R, Zuanazzi JA. (1998). Antiinflammatory and antinociceptive activities of extracts and isolated compounds from Stachytarpheta cayennensis. J Ethanopharmacolgy; 60(1), 5359.PMID: 9533432

5. Brown SE, McLaughlin WA. (2011). Identification of lethal yellowing group (16SrIV) of phytoplasmas in the weeds Stachytarpheta jamaicensis, Macroptilium lathyroides and Cleome rutidosperma in Jaimaica. Phytopathogenic mollicutes; 1: 27-34.doi: 10.5958/j.2249-4669.1.1.004

6. Alice CB, Vargas, VM, Silva GA, Siqueria NC, Schapoval EE, Gleeve J. (1991). Screening of plants used in south Brazilian folk medicine. J Ethnopharmacol; 35:165-71. https://doi.org/10.1016/0378-8741(91)90069-P

7. Kooiman P. (1975). The occurrence of iridoids glycosides in the verbenaceae. Acta Bot Neerl ; 24:459-68. doi: 10.1111/j.1438-8677.1975.tb01035.x 
8. Futuro DO.(1997). Stachytarpheta cayennensis consider acoesquimica ecologicas. Ph.D thesis. R.J.Brazil: Universidade Federal do Rio de Janeiro.

9. Pardo F, Perich F, Villarroel L, Torres R. (1993). Isolation of verbascoside, an antimicrobial constituent of Buddle jaglobosa leaves". J Ethnopharmacol; 39 (3): 221-2. doi:10.1016/0378-8741(93)90041-3. PMID 8258981.

10. Guillermo AJ, De Liverant JG, MartíNez A, MartíNez G, Muñoz JL, Arciniegas A, Romo DA. (1999). Mode of action of Buddle jacordata verbascoside against Staphylococcus aureus. J Ethnopharmacology ; 66 (1): $75-$ 8. doi:10.1016/S0378-8741(98)00203-7. PMID 10432210

11. Speranza L, Franceschelli S, Pesce M, Menghini L, Patruno A, Vinciguerra I, De Lutiis MA, Felaco M.( 2009). Antiinflammatory properties of the plant Verbascum mallophorum. Journal of Biological Regulators and Homeostatic Agents; 23 (3): 189-95. PMID 19828096.

12. Santoro A, Bianco G, Picerno P, Aquino RP, Autore G, Marzocco S, Gazzerro P, Lioi MB, Bifulco M. (2008). Verminoside- and verbascoside-induced genotoxicity on human lymphocytes: Involvement of PARP-1 and p53 proteins. Toxicology Letters; 178 (2): 71-6. doi:10.1016/j.toxlet.2008.02.006. PMID 18395372.

13. Herbert JM, Maffrand JP, Taoubi K, Augereau JM, Fouraste I, Gleye J. (1991). Verbascoside isolated from Lantana camara, an inhibitor of protein Kinase C. Journal of Natural Products; 54 (6): $1595-600$. doi:10.1021/np50078a016. PMID 1812212

14. Murashige T, Skoog F. (1962). A revised medium for rapid growth and bioassay with tobacco tissue culture. Physiol. Plant; 159, 473-497.doi: 10.1111/j.1399-3054.1962.tb08052.x

15. Doyle JL, Doyle JL. (1990). Isolation of plant DNA from fresh tissue. Focus;75 (1),1315.ci.nii.ac.jp/naid/2000086436

16. Gomaez KA, Gomez AA, Los B. (1976). Philippines: IRRI publ; 264pp.

17. Balaraju K, Agastian P, Preetamraj JP, Arokiyaraj S, Ignacimuthu S. (2008).Micropropagation of Vitexagnus-castus, (Verbenaceae) - a valuable medicinal plant. In Vitro Cellular \& Developmental Biology - Plant; 44, 436-441. doi: $10.1007 / \mathrm{s} 11627-008-9155-9$

18. Hiregoudar LV, Murthy HN, Bhat JG, Nayeem A, Hema BP, Hahn EJ, Paek KY. Rapid clonal propagation of Vitex trifolia; Biologiaplantarum. 2006; 50(2), 291-294.doi: 10.1007/s 10535-006-0023-3

19. Rahman MM, Bhadra SK. (2011). Development of protocol for in vitro propagation and conservation of Vitex negundo L. Int. J. Med. Arom. Plants; 3, 306-312.

20. Sujatha D, Ravi CH, Raghuvardhan L, Prasad B, Gulab Khan R, Sadanandam A, Christopher RT.( 2013). In vitro plantlet regeneration and genetic transformation of sponge gourd (Luffa cylindrica L.) African Journal of Plant Sciences; 7(6): 244-252. doi: 10.5897/AJPS12.196.

21. Rohela GK, Prasad B, Ravi CH, Rajender K, Christopher RT. (2015). In vitro clonal propagation of Rauwolfia tetraphylla, a relative of Indian snake root plant. Research Journal of Biotechnology; 10 (11):23-31. https://worldresearchjournals.com/biotek_backissue/vol(10)2015/.aspx

22. Mok MC, MokDWS, Armstrong DJ, Shudo K, Isogai Y, Okamoto T. (1982). Cytokinin activity of N-phenyl-N'-1, 2, 3-thidiazol-5-yl urea (thidiazuron), Phytochemistry; 21, 1509-151.doi: 10.1016/S0031-9422(82)85007-3

23. Rohela GK, Prasad B, Srinivas K, Sadanandam A, Ravi CH, Christopher RT.( 2013). In vitro Plantlet Regeneration from Leaf and Stem Calluses of Rauwolfia tetraphylla (R. canescens) and Confirmation of Genetic Fidelity of Plantlets Using the ISSR-PCR Method. Journal of Herbs, Spices \& Medicinal Plants; 19:66-75. doi:10.1080/10496475.2012.741056.

24. Rohela GK, Bylla P, Korra R, Reuben C. (2016). Phytochemical screening and antimicrobial activity of leaf, stem, root and their callus extracts in Rauwolfia tetraphylla. Int J AgricBiol; 18: 521-528.doi: 10.17957/IJAB/15.0120

25. Rohela GK, Santhosh D, Prasad B, Rajender K, Sreenu P,ChristopherT.(2016). Somatic embryogenesis and indirect regeneration in Mirabilis jalapa Linn. Materials Today: Proceedings; 3: 38823891.https://doi.org/10.1016/j.matpr.2016.11.045

26. Bylla P, Gulab Khan R, Radha T, Ravi CH, Venkataiah P, Subhash K, Christopher TR. (2013). DNA profiling of commercial chilli pepper (Capsicum annuum L.) varieties using random amplified polymorphic DNA (RAPD) markers. African Journal of Biotechnology; 12(30), pp. 4730-4735.

27. Rani V, Parida A, Raina SN.( 1995). Random amplified polymorphic DNA (RAPD) markers for genetic analysis in micropropagated plants of Populus deltoides Marsh. Plant Cell Rep; 14:459-462.PMID: 24185457 , doi: 10.1007/BF00234055

28. Soumen S, Sinchan A, Tulsi D, Parthadeb G. (2016). RAPD and ISSR based evaluation of genetic stability of micropropagated plantlets of Morus alba L. variety S-1. Meta Gene; 7: 7-15.

29. Sharma V, Nidhi B, Barkha K, AnoopKD, VikashSJ.( 2016). Assessment of Genetic Fidelity of in vitro raised plants in Swertia chirayita through ISSR, RAPD analysis and Peroxidase Profiling during Organogenesis. Braz. arch. biol. technol; 59: e16160389. http://dx.doi.org/10.1590/1678-4324-2016160389 